\title{
SUBSTANCE P RECEPTOR ON PAROTID CELL MEMBRANES
}

\author{
TFHMING IIANG ${ }^{1}$ AND MARGARET A. CASCIERI \\ Department of Biochemical Endocrinology, Merck Institute for Therapeutic Research, Merck Sharp \& Dohme Research Laboratories, \\ Rahway, New Jersey 07065
}

\begin{abstract}
A conjugate $\left({ }^{125} \mathrm{I}-\mathrm{BH}-\mathrm{SP}\right)$ between substance $\mathrm{P}$ and ${ }^{125} \mathrm{I}$-labeled Bolton-Hunter reagent binds reversibly to a single class of high affinity $\left(K_{d}=4 \mathrm{nM}\right)$ binding sites on dispersed rat parotid cells. The total number of binding sites is $49 \pm 17 \mathrm{fmol} / \mathrm{mg}$ of protein. The binding affinity of 13 fragments and analogs of substance $P$ correlates with their relative potency in stimulating salivation. The smallest fragment of substance $P$ which exhibits significant binding affinity and saliva-stimulating activity is the $\mathrm{COOH}$-terminal hexa(6-11)peptide. Structurally unrelated neurotransmitters and hormones do not affect the parotid cell binding of ${ }^{125}$ I-BH-SP. ${ }^{125}$ I-BII-SP pre-bound to the cells was recovered mainly in the particulate fractions of the cell homogenate. The ${ }^{125} \mathrm{I}-\mathrm{BH}-\mathrm{SP}$ binding activity of the parotid cells was inactivated by pretreatment of the cells with papain but not with ribonuclease A or deoxyribonuclease I. Our results suggest that ${ }^{125} \mathrm{I}-\mathrm{BH}-\mathrm{SP}$ binds to a substance $\mathrm{P}$ receptor on parotid membranes and that the receptor, at least in part, may be a protein.
\end{abstract}

Substance $P$ is present in the central nervous system and in nerve fibers of most peripheral tissues (Pernow, 1980; Nicoll et al., 1980; Nilsson and Brodin, 1977; Hokfelt et al., 1977). Substance $P$ neurons may constitute as many as $20 \%$ of all neurons in the spinal ganglia (Hokfelt et al., 1977) and $11 \%$ of neurons in the submucous plexus of the ileum (Costa et al., 1980). The undecapeptide exerts many pharmacological actions, including salivation (Leeman and Hammerschlag, 1967; Liang and Cascieri, 1979), vasodilation (Tregear et al., 1971), intestinal contraction (Tregear et al., 1971; Bury and Mashford, 1977), and depolarization of certain neurons (Konishi and Otsuka, 1974; Phillis and Limacher, 1974; Ogata, 1979). Although the physiological functions of substance $P$ have not been determined, its role as a neurotransmitter $/$ modulator has been implied from histochemical, electrophysiological, and pharmacological studies.

Substance $P$ may exert its actions by first interacting with a receptor which is poorly understood. We have reported previously our initial studies showing specific binding of a conjugate between substance $\mathrm{P}(\mathrm{SP})^{2}$ and ${ }^{125} \mathrm{I}$-Bolton-Hunter reagent $\left({ }^{125} \mathrm{I}-\mathrm{BH}\right)$ to dispersed rat parotid cells (Liang and Cascieri, 1980). We report here our additional characterization of the binding. The results

\footnotetext{
${ }^{1}$ To whom correspondence should be addressed at Merck Sharp \& Dohme Research Laboratories, P.O. Box 2000, Rahway, NJ 07065.

${ }^{2}$ The abbreviations used are: ACTH, adrenocorticotropic hormone; ${ }^{125} \mathrm{I}$ - $\mathrm{BH},{ }^{125} \mathrm{I}$-Bolton-Hunter reagent; C, cell pellet; LHRH, luteinizing hormone-releasing hormone; $\alpha$-MSH, $\alpha$-melanocyte-stimulating hormone; $\mathrm{P}$, the $500 \times g$ pellet of the sonicated cells; $\mathrm{S}$, the $500 \times g$ supernatant of the sonicated cells; SP, substance P; TRH, thyrotropinreleasing hormone.
}

suggest that the radioactive conjugate may bind to a substance $P$ receptor on parotid membranes.

\section{Materials and Methods}

Synthetic substance P, physalaemin, [Met]enkephalin, neurotensin, bradykinin, and angiotensin II were purchased from Beckman. Substance $P$ free acid, substance $P$ methyl ester, [Arg]vasopressin, and eledoisin were from Bachem, and chymostatin and eledoisin-related peptide were from the Protein Research Foundation in Osaka, Japan. Deca(2-11)substance P, nona (3-11)substance $P$, octa(4-11)substance $P$, [pyroGlu ${ }^{6}$ ]hexa(611)substance $P$, penta(7-11)substance $P$, tetra(811)substance $P, \quad$ tri(9-11)substance $P$, nona(19) substance $P,\left[D-A l a^{0}\right]$ hepta(5-11) substance $P$, kassinin, and ranatensin were purchased from Peninsula. Hepta(511) substance $P$ and somatostatin were kindly provided by Drs. L. S. Varga, D. F. Veber, F. W. Holly, and W. J. Paleveda of Merck Sharp \& Dohme Research Laboratories, West Point, PA. ACTH, LHRH, TRH, $\alpha$-MSH, acetylcholine, epinephrine, pancreatic ribonuclease A $(68$ units/mg), phospholipase C (Bacillus cereus, 145 units/ $\mathrm{mg}$ ), and phospholipase A (Crotalus terr. terr., 213 units/ $\mathrm{mg}$ ) were from Calbiochem, carbamyl choline was from Sigma, and collagenase (type I), papain (25 units $/ \mathrm{mg}$ ), and deoxyribonuclease I (2029 units/mg) were from Worthington. Monoiodinated ${ }^{125}$ I-Bolton-Hunter reagent, which was $1500 \mathrm{Ci} / \mathrm{mmol}$ at the time of purchase and used within 1 month, was purchased from Amersham.

Preparation of ${ }^{125} \mathrm{I}$-BH-substance $P .{ }^{125} \mathrm{I}$-BH-SP was prepared as previously described (Liang and Cascieri, 
1980) with minor modifications. Monoiodinated ${ }^{125}$ I-Bolton-Hunter reagent $(1 \mathrm{mCi})$ was flushed with nitrogen to evaporate the solvent. Substance P (5 $\mu \mathrm{g}$ in $20 \mu \mathrm{l}$ of 0.1 M sodium borate, $\mathrm{pH} 8.5$, and $1.3 \mathrm{~mm}$ acetic acid) was added to the tube and was incubated at $0^{\circ} \mathrm{C}$ for $1 \mathrm{hr}$. The reaction mixture was purified by thin layer chromatography on Whatman K6 plates in 1-butanol:pyridine: acetic acid:water $(\mathrm{v} / \mathrm{v}, 4: 1: 1: 2)$. The recovery and extraction of the ${ }^{125} \mathrm{I}-\mathrm{BH}-\mathrm{SP}$ from the silica gel was carried out in anaerobic conditions as previously described to avoid oxidation of the methionine residue (Liang and Cascieri, 1980). The molarity of ${ }^{125} \mathrm{I}-\mathrm{BH}-\mathrm{SP}$ shown in each experiment was calculated from the radioactivity after being corrected for decay and assuming $80 \%$ radiopurity (Liang and Cascieri, 1980).

Preparation of nonradioactive $B H$-SP. Monoiodinated $N$-succinimidyl-3-(4-hydroxyphenyl)propionate was prepared as described by Bolton and Hunter (1973) except that $\mathrm{Na}^{125} \mathrm{I}$ was replaced with $\mathrm{KI}$ in the reaction. For conjugation, the reagent $(0.9 \mu \mathrm{mol})$ was incubated with substance $\mathrm{P}(0.74 \mu \mathrm{mol})$ in $0.1 \mathrm{M}$ borate buffer, $\mathrm{pH}$ 8.5 , at $0^{\circ} \mathrm{C}$ for $60 \mathrm{~min}$ in a final volume of $0.15 \mathrm{ml}$. The reaction mixture in three equal aliquots was chromatographed as described in the previous section. The plate was scraped into $0.5-\mathrm{cm}$ fractions and each fraction was extracted with $0.4 \mathrm{ml}$ of $15 \%$ pyridine, $50 \mathrm{~mm}$ mercaptoethanol. An aliquot $(0.05 \mathrm{ml})$ of the extract was assayed for saliva-stimulating activity in rats (procedures are described in a later section). Two major biologically active peaks were observed, one co-migrating with ninhydrin-positive substance $\mathbf{P}$ and the other co-migrating with ${ }^{125} \mathrm{I}-\mathrm{BH}-\mathrm{SP}$. The conjugate (BH-SP) fractions were pooled and the concentration was determined by amino acid analysis. Dansylation of the conjugate produced only dansyl lysine, whereas dansylation of substance $\mathrm{P}$ produced both the lysine and arginine derivatives, suggesting that the conjugation is at the $\alpha-\mathrm{NH}_{2}$-terminal.

Cell binding assay. The binding of ${ }^{125} \mathrm{I}-\mathrm{BH}-\mathrm{SP}$ to parotid cells was measured as before (Liang and Cascieri, 1980). Briefly, parotid cells, isolated by collagenase treatment of the minced gland (Liang and Cascieri, 1979), were incubated with ${ }^{125} \mathrm{I}-\mathrm{BH}-\mathrm{SP}(0.2$ to $0.4 \mathrm{nM})$ in $0.3 \mathrm{ml}$ of Krebs-Ringer phosphate buffer (120 mM NaCl, $4.8 \mathrm{~mm}$ $\mathrm{KCl}, 1.2 \mathrm{~mm} \mathrm{CaCl} 2,1.2 \mathrm{~mm} \mathrm{MgSO}_{4}$, and $15.6 \mathrm{~mm}$ sodium phosphate, pH 7.0) supplemented with $200 \mu \mathrm{g} / \mathrm{ml}$ of crystalline bovine serum albumin and $50 \mu \mathrm{g} / \mathrm{ml}$ of chymostatin. When indicated, competing compounds in $3 \mu \mathrm{l}$ of $0.1 \mathrm{M}$ acetic acid or dimethyl sulfoxide were included. After incubation, $0.1 \mathrm{ml}$ was layered on $0.3 \mathrm{ml}$ of $10 \%$ sucrose in Krebs-Ringer phosphate buffer and centrifuged for $1 \mathrm{~min}$ in a Beckman Microfuge to pellet the cells. The tubes were frozen in an acetone/dry ice bath and the tips were cut with a razor and counted in a Packard Gamma Counter with $71 \%$ counting efficiency. Other conditions are specified in individual experiments. Experiments were carried out in duplicate.

Salivation assay. The assay was a modification (Liang and Cascieri, 1979) of the procedure of Leeman and Hammerschlag (1967). Peptides were dissolved in $0.1 \mathrm{~N}$ acetic acid and were diluted in $0.15 \mathrm{M} \mathrm{NaCl}$ to the desired concentration immediately before injection. SpragueDawley male rats (body weight, 300 to $350 \mathrm{gm}$ ) were anesthetized with ether. The peptide solution $(0.1 \mathrm{ml})$ was injected via a tail vein and saliva was collected immediately from the buccal cavity with a Pasteur pipette over a period of $2 \mathrm{~min}$. The volume of saliva was measured by pipette. Three to five rats were used at each dosage level. Basal release of saliva was determined by injection of the vehicle alone.

Characterization of ${ }^{125} \mathrm{I}-\mathrm{BH}-\mathrm{SP}$ bound to parotid cells. Parotid cells ( $5 \mathrm{mg}$ of protein) were incubated with ${ }^{125} \mathrm{I}-\mathrm{BH}-\mathrm{SP}(2,110,000 \mathrm{dpm})$ in $3 \mathrm{ml}$ of Krebs-Ringer phosphate buffer, pH 7.0, supplemented with $200 \mu \mathrm{g} / \mathrm{ml}$ of bovine serum albumin and $50 \mu \mathrm{g} / \mathrm{ml}$ of chymostatin in the presence or absence of $2.5 \mu \mathrm{M}$ substance P. After 20 min at $20^{\circ} \mathrm{C},{ }^{125} \mathrm{I}-\mathrm{BH}-\mathrm{SP}$ bound to the cells was determined on a $0.1-\mathrm{ml}$ aliquot as above. The remainder of the cell suspension was centrifuged at $900 \times g$ for $20 \mathrm{sec}$. The cell pellet was washed twice with $10 \mathrm{ml}$ of ice cold Krebs-Ringer phosphate buffer. Finally, the cell pellet was resuspended in $2.1 \mathrm{ml}$ of cold Krebs-Ringer phosphate buffer with bovine serum albumin and chymostatin. The cells in $0.7 \mathrm{ml}$ of this suspension were pelleted at $900 \times g$ for $20 \mathrm{sec}$. The remainder of the suspension was sonicated for $1 \mathrm{~min}$ and then centrifuged at $500 \times \mathrm{g}$ for $10 \mathrm{~min}$. The cell pellet $(\mathrm{C})$ and the $500 \times \mathrm{g}$ pellet of the sonicated cells (P) were suspended in $0.5 \mathrm{ml}$ of $50 \%$ pyridine plus $50 \mathrm{~mm}$ mercaptoethanol and extracted at $0^{\circ} \mathrm{C}$ for $1 \mathrm{hr}$. Aliquots of $\mathrm{C}$ and $\mathrm{P}$ and the $500 \times \mathrm{g}$ supernatant (S) of the sonicated cells were "spiked" with $70,000 \mathrm{dpm}$ of authentic ${ }^{125} \mathrm{I}-\mathrm{BH}-\mathrm{SP}$ during this extraction to ascertain the stability of ${ }^{125} \mathrm{I}-\mathrm{BH}-\mathrm{SP}$ in this and subsequent steps. After $60 \mathrm{~min}, \mathrm{C}, \mathrm{P}$, and $\mathrm{S}$ were centrifuged at $1500 \times g$ for $10 \mathrm{~min}$. The supernatants were counted to determine the extent of extraction $(90 \%)$ and then evaporated under nitrogen. $\mathrm{C}, \mathrm{P}$, and $\mathrm{S}$ were taken up in $20 \mu \mathrm{l}$ of $50 \%$ pyridine plus $50 \mathrm{~mm}$ mercaptoethanol and chromatographed on thin layer plates as described above.

Enzyme treatment of cells. Parotid cells $(0.5 \mathrm{mg}$ of protein) were incubated in $2 \mathrm{ml}$ of Krebs-Ringer phosphate buffer, $\mathrm{pH} 7$, and $10 \mathrm{~mm}$ cysteine with or without enzymes (180 $\mu \mathrm{g}$ of papain, $50 \mu \mathrm{g}$ of deoxyribonuclease I, $50 \mu \mathrm{g}$ of ribonuclease $\mathrm{A}, 34 \mu \mathrm{g}$ of phospholipase $\mathrm{C}$, or 20 $\mu \mathrm{g}$ of phospholipase A) for $20 \mathrm{~min}$ at $20^{\circ} \mathrm{C}$. The cells then were diluted with ice cold Krebs-Ringer phosphate buffer $(5 \mathrm{ml})$ and centrifuged at $900 \times \mathrm{g}$ for $20 \mathrm{sec}$. The cell pellet was washed three times with $5 \mathrm{ml}$ of cold KrebsRinger phosphate buffer, suspended in $1 \mathrm{ml}$ of KrebsRinger phosphate buffer plus $200 \mu \mathrm{g} / \mathrm{ml}$ of bovine serum albumin and $50 \mu \mathrm{g} / \mathrm{ml}$ of chymostatin, and then used immediately to measure the binding of ${ }^{125} \mathrm{I}-\mathrm{BH}-\mathrm{SP}$. Papain was activated by incubation with $10 \mathrm{~mm}$ cysteine at $20^{\circ} \mathrm{C}$ for $30 \mathrm{~min}$ prior to the addition of the cells.

Under the conditions used in the cell treatment $(20$ min at $20^{\circ} \mathrm{C}$ in $2 \mathrm{ml}$ of Krebs-Ringer phosphate buffer, $\mathrm{pH} 7$ ), deoxyribonuclease I and ribonuclease A hydrolyzed greater than $70 \%$ of $250 \mu \mathrm{g}$ of DNA and RNA, respectively. L- $\alpha$-Palmitoyl-2-oleoyl-[ $\left.{ }^{14} \mathrm{C}\right]$ phosphatidylcholine $(0.02 \mu \mathrm{Ci}, 55 \mathrm{mCi} / \mathrm{mmol}$; Applied Science Laboratories) was hydrolyzed $90 \%$ and $80 \%$ by phospholipase $\mathrm{C}$ and phospholipase $\mathrm{A}$, respectively.

Protein determination. Cells were either sonicated or homogenized and the protein concentration was deter- 


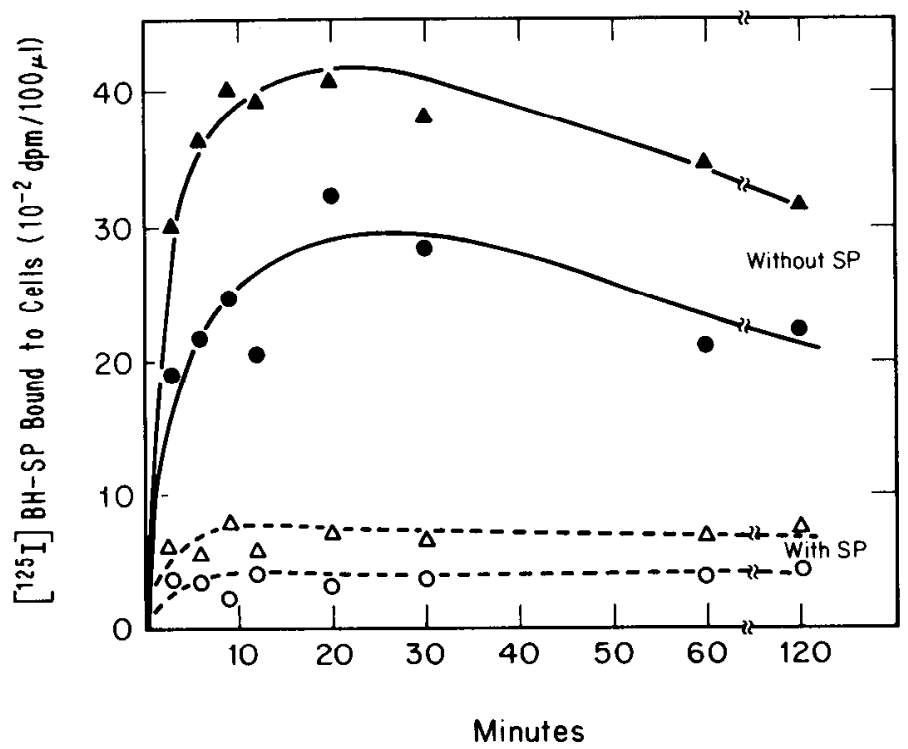

Figure 1. Time course of ${ }^{125} \mathrm{I}-\mathrm{BH}-\mathrm{SP}$ binding to rat parotid cells. Isolated parotid cells (2.8 mg of protein) were incubated with two levels of ${ }^{125}$ I-BH-SP $(611,000$ or $1,159,000 \mathrm{dpm})$ in the presence or absence of substance $P(2.5 \mu \mathrm{M})$ in a final volume of $0.9 \mathrm{ml}$. The incubation was carried out at $18^{\circ} \mathrm{C}$. At intervals, 0.1 $\mathrm{ml}$ of the incubation mixture was removed for determining the amount of radioactivity bound to cells. $-\mathrm{O}_{-}-\mathrm{O}$, $611,000 \mathrm{dpm}\left(2 \times 10^{-10} \mathrm{M}\right)$ of ${ }^{125} \mathrm{I}-\mathrm{BH}-\mathrm{SP} ; \Delta-\Delta, \triangle \triangle_{-}-\triangle$, $1,159,000 \mathrm{dpm}\left(3.8 \times 10^{-10} \mathrm{M}\right)$ of ${ }^{125} \mathrm{I}-\mathrm{BH}-\mathrm{SP}$. mined by the method of Bradford (1976) using bovine $\gamma$-globulin as the standard.

\section{Results}

Parotid cell preparations readily degrade ${ }^{125} \mathrm{I}-\mathrm{BH}-\mathrm{SP}$; therefore, in order to demonstrate specific binding of ${ }^{125} \mathrm{I}$ BH-SP to parotid cells, it is necessary to perform the experiments in the presence of chymostatin using low concentrations of cells at moderately low temperatures $\left(18\right.$ to $\left.25^{\circ} \mathrm{C}\right)$. Figure 1 shows the time course of ${ }^{125} \mathrm{I}-\mathrm{BH}$ SP binding to collagenase-dispersed parotid cells using two levels (2 and $3.8 \times 10^{-10} \mathrm{M}$ ) of ${ }^{125} \mathrm{I}-\mathrm{BH}-\mathrm{SP}$. The binding is rapid and reaches a maximum level between 10 and $20 \mathrm{~min}$ and decreases after $30 \mathrm{~min}$. The binding in the presence of $2.5 \mu \mathrm{M}$ substance $\mathrm{P}$ is much lower, does not change during the period $(3 \mathrm{~min}$ to $2 \mathrm{hr}$ ) of incubation, and is referred to as nonspecific binding. Figure 2 shows a representative experiment showing the dose-dependent inhibition of ${ }^{125} \mathrm{I}-\mathrm{BH}-\mathrm{SP}$ binding to the cells. The inhibition reaches a plateau between 0.25 and $2.5 \mu \mathrm{M}$ substance $P$. The binding that can be inhibited by $2.5 \mu \mathrm{M}$ substance $\mathrm{P}$ is referred to as specific binding and is $85 \%$ to $95 \%$ of the total. Time course studies carried out at $0^{\circ} \mathrm{C}$ and at $37^{\circ} \mathrm{C}$ showed that maximum specific binding was only $10 \%$ and $30 \%$, respectively, of that at $20^{\circ} \mathrm{C}$. The binding studies to be described below were carried out at approximately $20^{\circ} \mathrm{C}$ for $20 \mathrm{~min}$. The cell-bound radioactivity can be extracted with $50 \%$ pyridine and at least

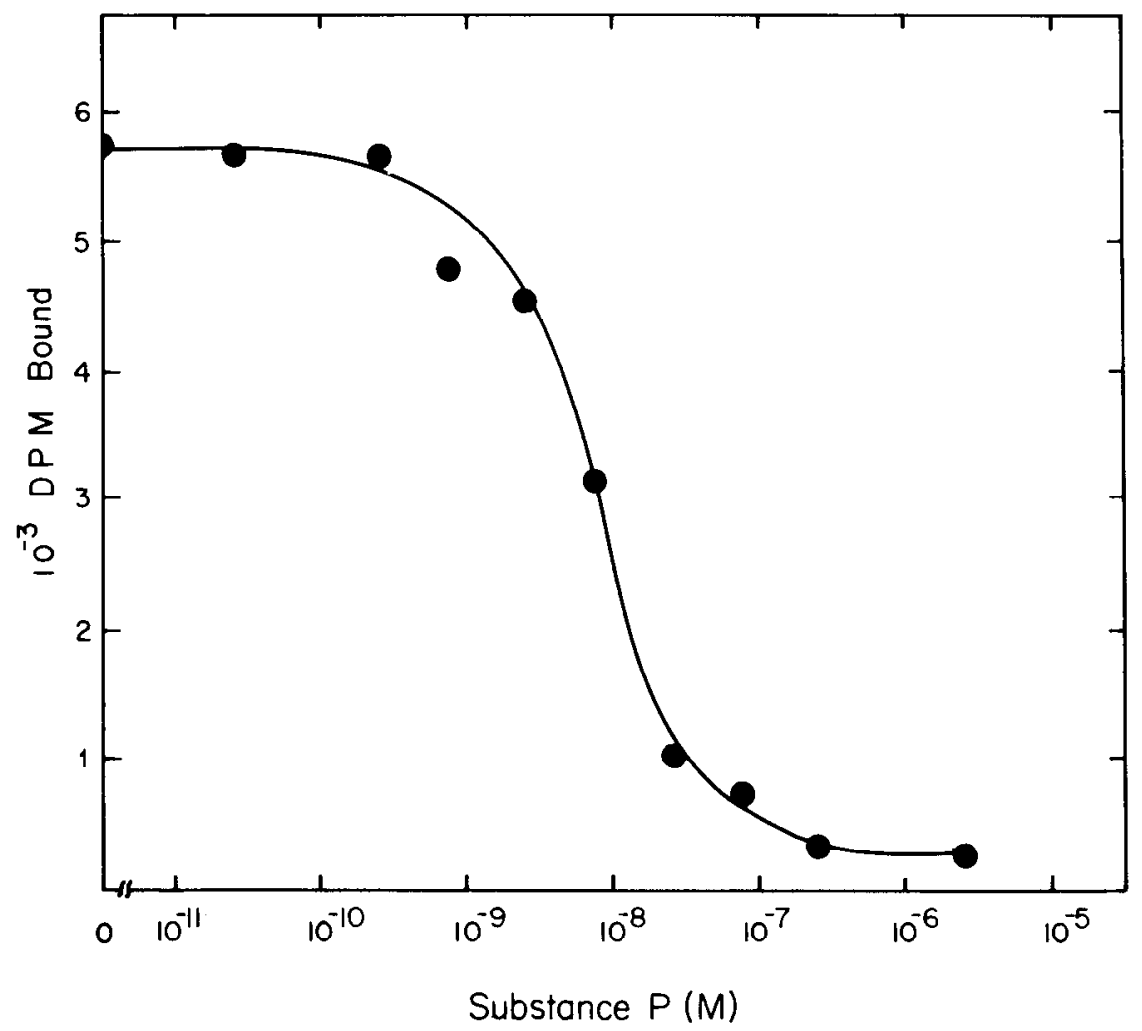

Figure 2. Inhibition of parotid cell binding of ${ }^{125} \mathrm{I}-\mathrm{BH}-\mathrm{SP}$ by substance $\mathrm{P}$. Isolated parotid cells (1.04 mg of protein) were incubated with ${ }^{125} \mathrm{I}-\mathrm{BH}-\mathrm{SP}(282,000$ dpm, $\left.3.3 \times 10^{-10} \mathrm{M}\right)$ and substance $\mathrm{P}$ at the concentrations indicated on the abscissa. The final volume was $0.3 \mathrm{ml}$. After $25 \mathrm{~min}$ at $25^{\circ} \mathrm{C}, 0.1 \mathrm{ml}$ of the incubation mixture was removed for determining the amount of radioactivity bound to the cells. 
$80 \%$ of the radioactivity extracted co-chromatographed with ${ }^{125} \mathrm{I}-\mathrm{BH}-\mathrm{SP}$ (data not shown). These results suggest that parotid cells reversibly bind intact ${ }^{125} \mathrm{I}-\mathrm{BH}-\mathrm{SP}$.

Figure 3 shows the inhibition of ${ }^{125} \mathrm{I}-\mathrm{BH}-\mathrm{SP}$ binding to parotid cells by $\mathrm{BH}-\mathrm{SP}$ which is radio-inert but otherwise identical to ${ }^{125} \mathrm{I}-\mathrm{BH}-\mathrm{SP}$. Scatchard analysis of these data indicates that the parotid cells appear to have a single type of specific binding site. The apparent dissociation constant $\left(K_{d}\right)$ is $4.0 \pm 1.8 \mathrm{nM}$ (mean $\pm \mathrm{SD}$, four experiments) with $49 \pm 17 \mathrm{fmol}$ of binding sites per $\mathrm{mg}$ of protein. The number of binding sites per cell was not determined since the cell preparation still contains undispersed lobules which precludes an accurate determination of the cell number. Complete cell dispersion could be achieved by using more strenuous conditions during tissue digestion (e.g., $5 \mathrm{mg} / \mathrm{ml}$ of collagenase at $37^{\circ} \mathrm{C}$ for $1 \mathrm{hr}$ ), however, such preparations were unresponsive to substance P (Liang and Cascieri, 1979).

In a series of experiments, various fragments and analogs of substance $P$ were titrated for their ability to inhibit the parotid cell binding of ${ }^{125} \mathrm{I}-\mathrm{BH}-\mathrm{SP}$ in order to determine if their binding affinities correlate with their potency in stimulating salivation in rats. Figure 4 summarizes the results of the competition of the cell binding of ${ }^{125} \mathrm{I}-\mathrm{BH}$-SP by fragments of substance $\mathrm{P}$. The potency of the fragments of substance $P$ decreases as the chain length decreases from the $\mathrm{NH}_{2}$-terminal. The smallest fragment of substance $P$ which exhibits significant inhibitory activity is the hexa(6-11)peptide. Further decreases in the chain length drastically decrease potency. Thus, the penta(7-11)peptide is a very weak competitor; the tetra(8-11)- and the tri(9-11)peptides, even at very high concentrations, do not compete for the cell binding of
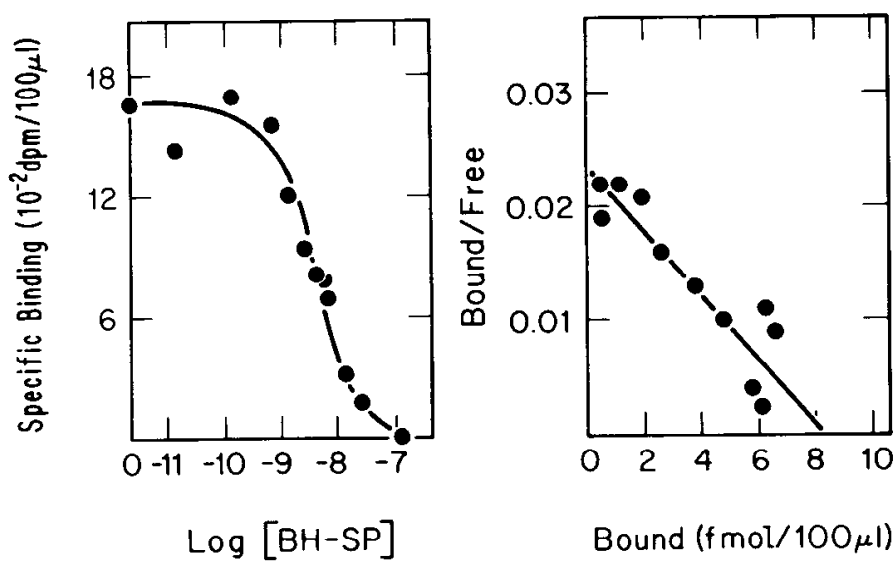

Figure 3. Inhibition of parotid cell binding of ${ }^{125} \mathrm{I}-\mathrm{BH}-\mathrm{SP}$ by radio-inert BH-SP and Scatchard analysis of the binding. Left, Parotid cells ( $0.7 \mathrm{mg}$ of protein) were incubated with ${ }^{125} \mathrm{I}$-BH$\mathrm{SP}\left(214,000 \mathrm{dpm}, 2 \times 10^{-10} \mathrm{M}\right)$ and various concentrations of nonradioactive BH-SP in a final volume of $0.3 \mathrm{ml}$. After $25 \mathrm{~min}$ at $25^{\circ} \mathrm{C}, 0.1 \mathrm{ml}$ of the incubation mixture was removed to determine cell-bound radioactivity. The binding in the presence of $2.5 \mu \mathrm{M}$ substance $\mathrm{P}$ (i.e., nonspecific binding) also was determined $(172 \mathrm{dpm})$ and this value was subtracted. Right, Scatchard analysis of the data on the left. From this and three similar experiments, the apparent dissociation constant $\left(K_{d}\right)$ was calculated to be $4.0 \pm 1.8 \mathrm{nM}\left(K_{d}=-1 /\right.$ slope $)$ and the number of total binding sites calculated from the abscissa was $49 \pm 17 \mathrm{fmol} / \mathrm{mg}$ of protein (mean $\pm \mathrm{SD}$ ).

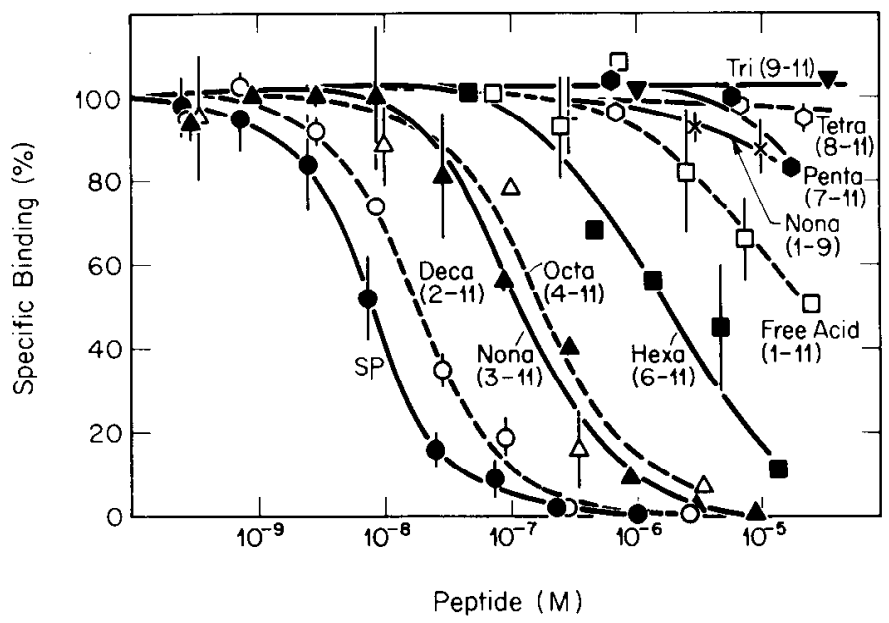

Figure 4. Competition of parotid binding of ${ }^{125} \mathrm{I}-\mathrm{BH}-\mathrm{SP}$ by substance $\mathrm{P}$ and its fragments. Substance P: $\mathrm{Arg}^{1}-\mathrm{Pro}-\mathrm{Lys}^{3}-\mathrm{Pro}$ Gln ${ }^{5}$-Gln-Phe ${ }^{7}$-Phe-Gly ${ }^{9}$-Leu-Met ${ }^{11}-\mathrm{NH}_{2}$. ${ }^{125}$ I-BH-SP $(211,000$ $\mathrm{dpm})$ was incubated with parotid cells $(0.5 \mathrm{mg}$ of protein) in the absence and presence of a competing peptide in a final volume of $0.3 \mathrm{ml}$ at $20^{\circ} \mathrm{C}$ for $20 \mathrm{~min}$. After incubation, $0.1 \mathrm{ml}$ was removed to determine the cell-bound radioactivity. The specific binding was calculated by subtracting the binding in the presence of $2.5 \mu \mathrm{M}$ substance $\mathrm{P}$ from the total binding. The specific binding in the absence of a competitor was taken as $100 \%$. The bars indicate the standard deviation in the number of experiments given in Table I.

${ }^{125}$ I-BH-SP. Deanidated substance $P$ (substance $P$ free acid) has a binding affinity three orders of magnitude lower than that of substance $P$. The nona(1-9)peptide is a much weaker competitor. The concentrations of these peptides required to inhibit the cell binding of ${ }^{125} \mathrm{I}-\mathrm{BH}$ $\mathrm{SP}$ by $50 \%\left(\mathrm{IC}_{50}\right)$ were estimated from their titration curves and are listed in Table I. Not included in the figure is a hepta(5-11) fragment preparation consisting of $50 \%$ pyroglutamyl and $50 \%$ glutamyl residues at the $\mathrm{NH}_{2}$-terminal which has an inhibitory potency similar to the octa(4-11)peptide.

The cell binding of ${ }^{125} \mathrm{I}-\mathrm{BH}-\mathrm{SP}$ could be inhibited by biologically active analogs of substance $P$ and their values of $\mathrm{IC}_{50}$ are listed in Table I. Physalaemin and the conjugate (BH-SP) between substance $\mathrm{P}$ and the radio-inert Bolton-Hunter reagent both are slightly more potent competitors than substance P. Substance P methyl ester, a biologically active analog (Cascieri et al., 1981) in which the $\mathrm{COOH}$-terminal amide has been replaced by a methyl ester, is a less potent competitor. [D-Ala $\left.{ }^{0}\right] \mathrm{Hepta}(5-$ 11) substance $P$, eledoisin, kassinin, and eledoisin-related peptide are also effective competitors.

Figure 5 shows the dose-dependent stimulation of salivation in ether-anesthetized rats by fragments of substance $P$. The doses of these peptides required to produce half-maximal stimulation of salivation $\left(\mathrm{ED}_{50}\right)$ were estimated from these curves and are listed in Table I. Other analogs of substance $P$ also were evaluated for their potency to stimulate salivation and their values of $\mathrm{ED}_{50}$ are included in Table I. Physalaemin and BH-SP are slightly more potent than substance $\mathbf{P}$ in stimulating salivation. Other peptides are all less potent than substance $P$. 
The relative receptor binding affinity and the relative biological potency of these peptides were calculated by comparison of their values of $\mathrm{IC}_{50}$ and $\mathrm{ED}_{50}$, respectively (Table I). Figure 6 is a graphic presentation of these

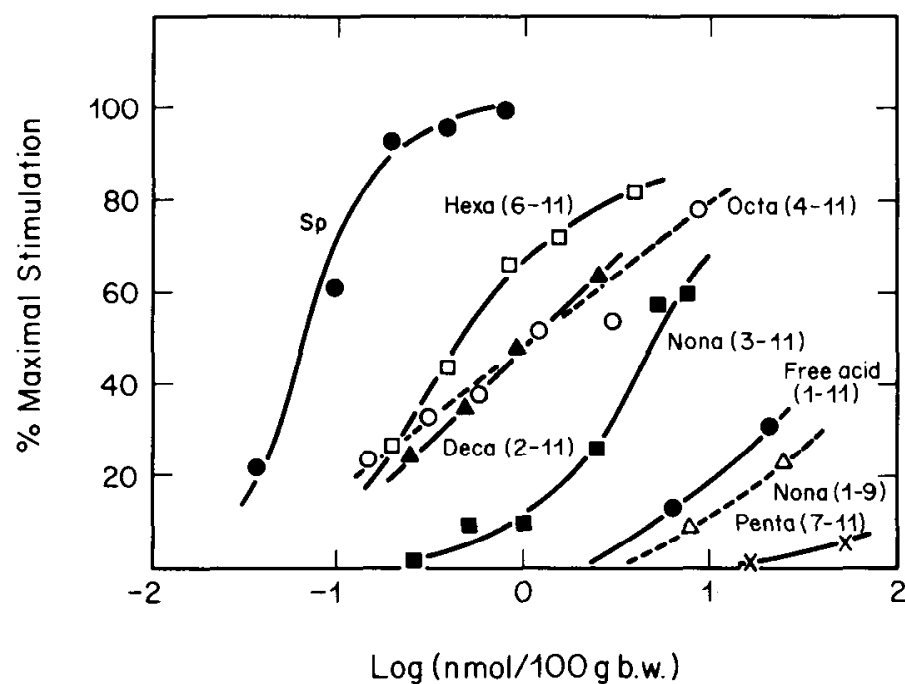

Figure 5. Stimulation of salivation in rats by substance $P$ and its fragments. The assay is described under "Materials and Methods." The maximum stimulation produced by substance $\mathrm{P}$, considered to be $100 \%$, was $384 \pm 39 \mu \mathrm{l} / \mathrm{rat}$ (seven experiments) which compared to a basal level of $2 \pm 1.6 \mu \mathrm{l} / \mathrm{rat}$. Not included in the figure are data for the tetra(8-11)- and tri(911)peptides which had no effect on salivation up to the highest concentration tested ( $50 \mathrm{nmol} / 100 \mathrm{gm}$ of body weight $(\mathrm{g} \mathrm{b.w}$.$) ).$ results. Excellent correlation between the relative receptor binding affinity and the relative saliva-stimulating potency was obtained with physalaemin, BH-SP, DAla $^{0}(5-11)$, octa(4-11), SP methyl ester, (1-11)free acid, and penta(7-11). However, eledoisin and hexa(pyroGlu' ${ }^{6}$ 11) exhibited a greater (15- and 34-fold, respectively) potency in stimulating salivation than their relative receptor affinity would predict, whereas the deca(2-11)and nona(3-11)peptides have a receptor binding affinity about 7 - to 10-fold higher than their saliva-stimulating potency. Nevertheless, the overall correlation is good (correlation coefficient, 0.92).

Table II summarizes a representative experiment showing the subcellular distribution of the radioactivity pre-bound to the cells. A comparison of the radioactivity in the respective fractions between ${ }^{125} \mathrm{I}-\mathrm{BH}-\mathrm{SP}$ bound in the absence and in the presence of substance $\mathrm{P}(2.5 \mu \mathrm{M})$ indicates that the radioactivity in all three particulate fractions decreased to a much greater extent than did the cytosol fraction when substance $P$ was present in the binding incubation. Seventy-six percent of the specific binding was recovered in the $500 \times g$ pellet. In one experiment, the radioactivity in the $500 \times g$ pellet was extracted with pyridine (50\%) and $80 \%$ of the radioactivity co-chromatographed with authentic ${ }^{125} \mathrm{I}-\mathrm{BH}-\mathrm{SP}$ on thin layer chromatography. These results suggest that the specific binding site is mainly, if not entirely, present in membranes.

Table III shows that pretreatment of the cells with papain at $20^{\circ} \mathrm{C}$ for $15 \mathrm{~min}$ decreases ${ }^{125} \mathrm{I}-\mathrm{BH}-\mathrm{SP}$ binding

TABLE I

Comparison of receptor binding affinity and saliva-stimulating potency for substance $P$ fragments and analogs

The concentrations of the peptides required to inhibit specific binding of ${ }^{125} \mathrm{I}-\mathrm{BH}-\mathrm{SP}$ to parotid cells by $50 \%$ (IC $\mathrm{C}_{50}$ ) were estimated from titration curves such as those in Figure 4. The doses of the peptides required to stimulate $50 \%$ of maximum ( $\left.\mathrm{ED}_{50}\right)$ salivation in rats were estimated from titration curves such as those in Figure 5. Some peptides at the dosages tested did not reach $50 \%$ maximum effect and their $\mathrm{IC}_{30}$ and $\mathrm{ED}_{50}$ were estimated by extrapolation of the curves. Where possible, the values of $\mathrm{IC}_{50}$ and $\mathrm{ED}_{50}$ are given as the mean $\pm \mathrm{SD}$ of the number of experiments shown in parentheses. The relative receptor binding affinity and the relative potency for salivation were calculated by comparisons of $\mathrm{IC}_{50}$ and $\mathrm{ED}_{50}$ values, respectively, with those of substance $\mathrm{P}$. The amino acid sequences of substance $P$ analogs are: physalaemin, pyroGlu-AlaAsp-Pro-Asn-Lys-Phe-Tyr-Gly-Leu-Met- $\mathrm{NH}_{2}$; eledoisin, pyroGlu-Pro-Ser-Lys-Asp-Ala-Phe-Ile-Gly-Leu-Met-NH ${ }_{2}$; kassinin, Asp-Val-Pro-LysSer-Asp-Gln-Phe-Val-Gly-Leu-Met- $\mathrm{NH}_{2}$; and eledoisin-related peptide, Lys-Phe-Ile-Gly-Leu-Met-NH .

\begin{tabular}{|c|c|c|c|c|c|}
\hline \multirow[b]{2}{*}{ Peptide } & \multicolumn{2}{|c|}{ Receptor Binding } & \multicolumn{3}{|c|}{ Salivation } \\
\hline & IC & $\begin{array}{l}\text { Relative } \\
\text { Affinity }\end{array}$ & $\mathrm{ED}_{50}$ & & $\begin{array}{l}\text { Relative } \\
\text { Potency }\end{array}$ \\
\hline & $M$ & & $\begin{array}{l}\text { nmol/100 gm } \\
\text { body wt. }\end{array}$ & & \\
\hline SP & $1.3 \pm 0.9 \times 10^{-8}(15)$ & 1.0 & $0.08 \pm 0.029$ & (7) & 1.0 \\
\hline SP free acid(1-11) & $9.0 \pm 0.1 \times 10^{-6}(2)$ & 0.0014 & 60 & (1) & 0.0014 \\
\hline $\operatorname{Deca}(2-11) S P$ & $2.0 \pm 0.3 \times 10^{-8}(2)$ & 0.65 & $1.19 \pm 0.42$ & (2) & 0.068 \\
\hline Nona(3-11)SP & $1.1 \pm 0.4 \times 10^{-7}(2)$ & 0.12 & $4.7 \pm 0.56$ & (2) & 0.017 \\
\hline Nona(1-9)SP & $\sim 2 \times 10^{-4}$ & 0.00006 & 126 & (1) & 0.00064 \\
\hline Octa $(4-11) \mathrm{SP}$ & $1.6 \pm 0.3 \times 10^{-7}(2)$ & 0.08 & 1.26 & (1) & 0.064 \\
\hline Hexa(pyroGlu $\left.{ }^{6}-11\right) S P$ & $2.6 \pm 0.9 \times 10^{-6}(2)$ & 0.005 & 0.48 & (1) & 0.169 \\
\hline Penta(7-11)SP & $\sim 2 \times 10^{-4}$ & 0.00006 & 500 & (1) & 0.00016 \\
\hline Tetra $(8-11) \mathrm{SP}$ & $>10^{-4}$ & $<0.0001$ & $>500$ & (1) & $<0.00016$ \\
\hline Tri(9-11)SP & $>10^{-4}$ & $<0.0001$ & $>500$ & (1) & $<0.00016$ \\
\hline $\mathrm{BH}-\mathrm{SP}$ & $5.1 \pm 1.5 \times 10^{-9}(7)$ & 2.5 & 0.028 & (1) & 2.9 \\
\hline Physalaemin & $2.4 \pm 1.5 \times 10^{-9}(2)$ & 5.4 & 0.033 & (1) & 2.42 \\
\hline Eledoisin & $3.1 \pm 1.3 \times 10^{-7}(2)$ & 0.042 & $0.13 \pm 0.09$ & (2) & 0.62 \\
\hline SP methyl ester & $1.5 \pm 0.1 \times 10^{-7}(2)$ & 0.087 & $0.32 \pm 0.14$ & (3) & 0.25 \\
\hline$\left[\mathrm{D}-\mathrm{Ala}^{0}\right] \mathrm{Hepta}(5-11) \mathrm{SP}$ & $7.5 \times 10^{-8}$ & 0.17 & 0.48 & (1) & 0.17 \\
\hline Kassinin & $1.1 \times 10^{-6}$ & 0.012 & N.D. ${ }^{a}$ & & N.D. \\
\hline Eledoisin-related peptide & $1.6 \times 10^{-6}$ & 0.008 & N.D. & & N.D. \\
\hline
\end{tabular}

\footnotetext{
${ }^{a}$ N.D., not determined.
} 
activity by $69 \%$. Table III also shows that, when papain is washed away immediately after the protease is mixed with the cells, the ${ }^{125} \mathrm{I}-\mathrm{BH}-\mathrm{SP}$ binding activity is not affected. This latter result suggests that papain was effectively washed from the cells and that the lower binding activity of the cells pretreated with papain was due to the effect of papain on the cells but not due to any residual papain which might have degraded ${ }^{125} \mathrm{I}-\mathrm{BH}-\mathrm{SP}$ in the subsequent binding incubation. These results suggest that the substance $\mathrm{P}$ receptor, at least in part, may

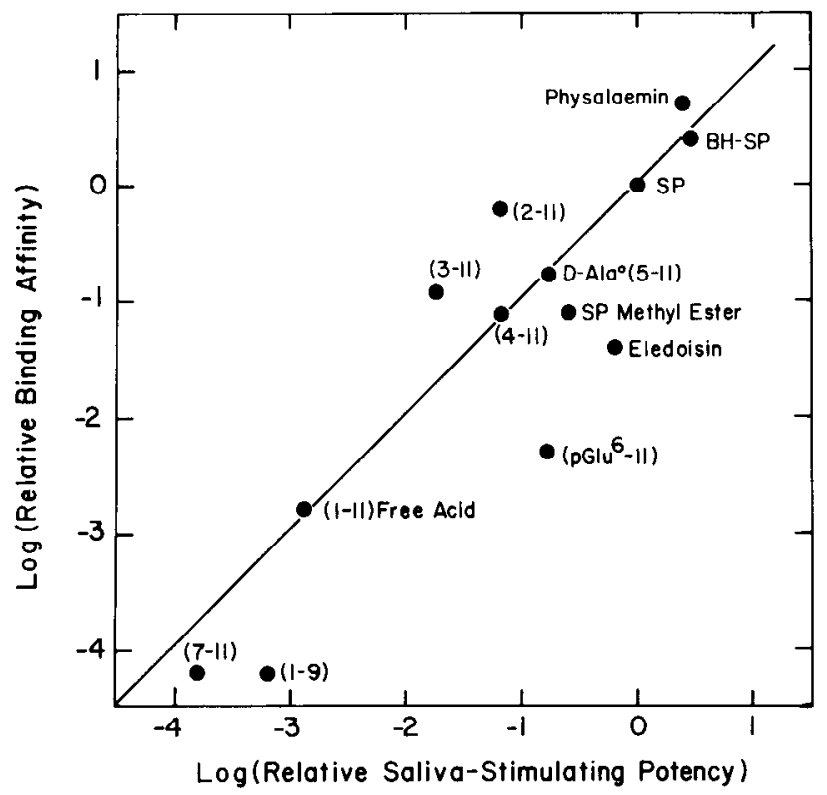

Figure 6. Correlation between the relative binding affinity to rat parotid cells and the relative saliva-stimulating activity for substance P-related peptides. The data are taken from Table I and their $\log$ values are plotted. The line is the theoretical correlation of 1.0. The correlation coefficient calculated from these data is 0.92 with a slope of 1.01 . be a protein. Pretreatment of the cells with deoxyribonuclease I or pancreatic ribonuclease $A$ does not affect the binding (Table III). The effect of phospholipase A and phospholipase $C$ treatment was variable and no conclusion can be made at the present time.

Structurally unrelated peptides and amines tested at concentrations up to 10 or $100 \mu \mathrm{M}$ did not show any significant effect on the parotid cell binding of ${ }^{125} \mathrm{I}-\mathrm{BH}$ SP. These are somatostatin, bradykinin, ranatensin, $\alpha-$ MSH, angiotensin II, neurotensin, TRH, epinephrine, acetylcholine, atropine, carbachol, and baclofen (Table IV). ACTH, LHRH, [Arg]vasopressin, and [Met]enkephalin have been previously shown to have no effect (Liang and Cascieri, 1980).

\section{TABLE III}

Effect of pretreatment of parotid cells with papain, ribonuclease, or deoxyribonuclease on the ${ }^{125} \mathrm{I}-\mathrm{BH}-\mathrm{SP}$ binding activity

Parotid cells were treated with the indicated enzymes and washed as described under "Materials and Methods." The pretreated cells then were assayed for ${ }^{125} \mathrm{I}$-BH-SP binding in the presence or absence of substance P $(2.5 \mu \mathrm{M})$ as described under "Materials and Methods." Each experiment was repeated three more times and similar results were obtained.

\begin{tabular}{lrcc}
\hline \multirow{2}{*}{$\begin{array}{c}\text { Pretreatment } \\
\text { of Cells }\end{array}$} & \multicolumn{3}{c}{${ }^{125}$ I-BH-SP Bound to Cells } \\
\cline { 2 - 4 } & & $d p m$ & $\begin{array}{c}\text { Specific } \\
\text { Binding }\end{array}$ \\
\hline Experiment 1 & & & \\
Control, 0 min & 2456 & 392 & $2064(84 \%)$ \\
Papain, 0 min & 2454 & 194 & $2260(92 \%)$ \\
Control, 15 min & 2725 & 282 & $2443(100 \%)$ \\
Papain, 15 min & 907 & 144 & $763(31 \%)$ \\
& & & \\
Experiment 2 & & & $1808(100 \%)$ \\
Control, 20 min & 3138 & 592 & $1614(90 \%)$ \\
DNase, 20 min & 2682 & 408 & $1632(90 \%)$ \\
RNase, 20 min & 2721 & 423 & \\
\hline
\end{tabular}

TABLE II

Subcellular distributions of radioactivity after pre-binding of ${ }^{125} I-B H$-SP to parotid cells

${ }^{125} \mathrm{I}$-BH-SP $\left(3.4 \times 10^{6} \mathrm{dpm}\right)$ was incubated with parotid cells $(0.84 \mathrm{mg}$ of protein) in the absence or presence $(2.4 \mu \mathrm{M})$ of substance $\mathrm{P}$ in KrebsRinger phosphate buffer, $\mathrm{pH} 7.0$, containing bovine serum albumin $(200 \mu \mathrm{g} / \mathrm{ml})$ and chymostatin $(50 \mu \mathrm{g} / \mathrm{ml})$ in a final volume of $6 \mathrm{ml}$. After $30 \mathrm{~min}$ at $20^{\circ} \mathrm{C}, 0.1 \mathrm{ml}$ of the incubation mixture was taken to determine cell-bound radioactivity. The remainder was centrifuged at $900 \times g$ for 20 sec and the cell pellet was washed with $10 \mathrm{ml}$ of ice cold Krebs-Ringer phosphate buffer, pH 7.0, containing bovine serum albumin. The washed cell pellet was suspended in $5 \mathrm{ml}$ of ice cold Krebs-Ringer phosphate buffer, $\mathrm{pH} 7.0$, and homogenized with a motor-driven Potter-Elvehjem glassglass homogenizer (Kontes; 25 strokes). Examination of the cells before and after homogenization under a microscope showed that about $95 \%$ of the cells were broken by the homogenization. The homogenate was fractionated by differential centrifugation at $500 \times g$ for 10 min, $10,000 \times g$ for $10 \mathrm{~min}$, and $300,000 \times g$ for $60 \mathrm{~min}$. The pellets were suspended in Krebs-Ringer phosphate buffer, pH 7.0, and aliquots of each fraction were taken to determine radioactivity and protein. The data presented are the total protein and total radioactivity in each fraction. All cell fractionation procedures were carried out at 0 to $4^{\circ} \mathrm{C}$. Although the protein concentration in the $500 \times g$ pellet and the $300,000 \times g$ supernatant differs between cells incubated in the presence or absence of substance $\mathbf{P}$ in this experiment, additional experiments indicate that the variation is not consistent and is not due to substance $P$.

\begin{tabular}{|c|c|c|c|c|c|}
\hline & \multicolumn{2}{|c|}{ Protein } & \multicolumn{3}{|c|}{ Radioactivity } \\
\hline & Without SP & With SP & Without SP & With SP & $\begin{array}{c}\text { Ratio: } \\
\text { Withnut/With SP }\end{array}$ \\
\hline & \multicolumn{2}{|c|}{$m g$} & \multicolumn{2}{|c|}{$d p m$} & \\
\hline Whole cell & & & 89,218 & 8,704 & 10 \\
\hline $500 \times g$ pellet & 2.9 & 4.6 & 58,120 & 4,885 & 12 \\
\hline $10,000 \times g$ pellet & 0.13 & 0.14 & 1,800 & 197 & 9 \\
\hline $300,000 \times g$ pellet & 0.07 & 0.07 & 677 & 56 & 12 \\
\hline $300,000 \times g$ supernatant & 6.8 & 5.7 & 16,221 & 4,923 & 3 \\
\hline
\end{tabular}


TABLE IV

Ligand specificity of ${ }^{125} I-B H$-SP binding to isolated rat parotid cells

The binding assays were carried out as in Figure 4. Each compound was repeated one more time and similar results were obtained.

\begin{tabular}{|c|c|}
\hline Competitor & $\begin{array}{l}{ }^{125} \mathrm{I}-\mathrm{BH}-\mathrm{SP} \\
\text { Bound to Cells }\end{array}$ \\
\hline & $d p m$ \\
\hline \multicolumn{2}{|l|}{ Experiment 1} \\
\hline Control & 4254 \\
\hline $\mathrm{SP}, 2.5 \times 10^{-6} \mathrm{M}$ & 117 \\
\hline \multicolumn{2}{|l|}{ Bradykinin } \\
\hline $10^{-6} \mathrm{M}$ & 3699 \\
\hline $10^{-5} \mathrm{M}$ & 4602 \\
\hline \multicolumn{2}{|l|}{ Ranatensin } \\
\hline $10^{-6} \mathrm{M}$ & 3724 \\
\hline $10^{-5} \mathrm{M}$ & 3815 \\
\hline \multicolumn{2}{|l|}{$\alpha-\mathrm{MSH}$} \\
\hline $10^{-6} \mathrm{M}$ & 3409 \\
\hline $10^{-5} \mathbf{M}$ & 4063 \\
\hline \multicolumn{2}{|l|}{ Angiotensin II } \\
\hline $10^{-6} \mathrm{M}$ & 3713 \\
\hline $10^{-5} \mathbf{M}$ & 3734 \\
\hline \multicolumn{2}{|l|}{ Somatostatin } \\
\hline $10^{-6} \mathrm{M}$ & 3999 \\
\hline $10^{-5} \mathbf{M}$ & 3854 \\
\hline \multicolumn{2}{|l|}{ Neurotensin } \\
\hline $10^{-6} \mathrm{M}$ & 3403 \\
\hline $10^{-5} \mathbf{M}$ & 3937 \\
\hline $\mathrm{TRH}, 10^{-5} \mathbf{M}$ & 3475 \\
\hline Epinephrine, $10^{-4} \mathrm{M}$ & 3765 \\
\hline \multicolumn{2}{|l|}{ Experiment 2} \\
\hline Control & 3737 \\
\hline $\mathrm{SP}, 2.5 \times 10^{6} \mathrm{M}$ & 169 \\
\hline \multicolumn{2}{|l|}{ Carbachol } \\
\hline $1 \times 10^{-6} \mathbf{M}$ & 3497 \\
\hline $1 \times 10^{-5} \mathrm{M}$ & 3679 \\
\hline \multicolumn{2}{|l|}{ Acetylcholine } \\
\hline $1 \times 10^{-5} \mathrm{M}$ & 4107 \\
\hline $1 \times 10^{-4} \mathrm{M}$ & 3866 \\
\hline \multicolumn{2}{|l|}{ Atropine } \\
\hline $1 \times 10^{-5} \mathrm{M}$ & 3756 \\
\hline $1 \times 10^{-4} \mathrm{M}$ & 3087 \\
\hline \multicolumn{2}{|l|}{ Baclofen } \\
\hline $1 \times 10^{-5} \mathrm{M}$ & 3315 \\
\hline $1 \times 10^{-4} \mathrm{M}$ & 3689 \\
\hline
\end{tabular}

\section{Discussion}

Acylation of the $\mathrm{NH}_{2}$-terminal of substance $\mathrm{P}$ with Bolton-Hunter reagent, which has been widely used to label peptides (Langone, 1980), produces a conjugate which is slightly more potent than substance $P$ in stimulating salivation and which has high affinity for a substance $P$ binding site on the rat parotid cells. A good correlation was observed between the relative binding affinity of substance $P$ fragments and analogs and their relative saliva-stimulating activity. Although the parotid gland is only one of the tissues involved in salivation, Hanley et al. (1980a) and Brown and Hanley (1981) have reported a good correlation between the relative potency of substance $P$ fragments in stimulating salivation and their relative potency in stimulating the incorporation of $\left[{ }^{3} \mathrm{H}\right]$ inositol into phosphatidylinositol in parotid fragments and in stimulating amylase release from parotid gland slices, respectively. Thus, ${ }^{125} \mathrm{I}-\mathrm{BH}-\mathrm{SP}$ may bind to a substance $P$ receptor on the parotid cells.

Among reports (Hanley et al., 1980b; Nakata et al., 1978; Sjodin et al., 1980; Jensen and Gardner, 1979; Putney et al., 1980) attempting to demonstrate the binding of radioactive ligands to the substance $P$ receptor, our system exhibits higher total binding (disintegrations per min per mg of protein) and lower nonspecific binding than others. The nonspecific binding (i.e., ${ }^{125} \mathrm{I}-\mathrm{BH}-\mathrm{SP}$ binding which is not inhibited by excess substance $P$ (micromolar)) in our system is only $5 \%$ to $15 \%$ of the total binding. This compares favorably with the reported nonspecific binding of $40 \%$ to $50 \%$ for $\left[{ }^{3} \mathrm{H}\right]$ substance $\mathrm{P}$ binding to rat brain membranes (Hanley et al., 1980b), about $30 \%$ for $\left[{ }^{3} \mathrm{H}\right]$ substance $\mathrm{P}$ binding to rabbit brain membranes (Nakata et al., 1978), $38 \%$ for $\left[{ }^{125} \mathrm{I}^{\mathrm{T}} \mathrm{Tyr}{ }^{8}\right] \mathrm{sub}-$ stance $\mathbf{P}$ binding to guinea pig pancreatic cells (Sjodin et al., 1980), about $25 \%$ for ${ }^{125}$ I-physalaemin binding to guinea pig pancreatic cells (Jensen and Gardner, 1979), and $78 \%$ for ${ }^{125}$ I-physalaemin binding to rat parotid cells (Putney et al., 1980). We have compared the binding of $\left[{ }^{125}{ }^{12}-\mathrm{yyr}^{8}\right]$ substance $\mathrm{P}$ (from New England Nuclear) to rat parotid cells with that of ${ }^{125} \mathrm{I}-\mathrm{BH}-\mathrm{SP} .\left[{ }^{125} \mathrm{I}-\mathrm{Tyr}^{8}\right]$ Substance $\mathbf{P}$ showed lower total binding and higher nonspecific binding than did ${ }^{125}$ I-BH-SP. As a result, the specific binding of $\left[{ }^{125} \mathrm{I}-\mathrm{Tyr}^{8}\right]$ substance $\mathrm{P}$ was only $30 \%$ of that of ${ }^{125} \mathrm{I}-\mathrm{BH}$-SP.

It is known that substance $\mathrm{P}$ is readily oxidized to substance $P$ (methionine) sulfoxide upon exposure of a dilute solution even to air (Floor and Leeman, 1980). Preparation of ${ }^{125} \mathrm{I}$-physalaemin and $\left[{ }^{125} \mathrm{I}\right.$-Tyr $\left.{ }^{8}\right]$ substance $P$ involves exposure of the peptides to chloramine $T$ which might oxidize the methionine residue. The oxidized peptides may have a lower affinity for the substance $P$ receptor and may bind to nonreceptor sites more readily. We have noticed that ${ }^{125} \mathrm{I}-\mathrm{BH}-\mathrm{SP}$ exposed to air during purification (particularly during the scraping and extraction from the silica gel) exhibits variable binding to parotid cells. Upon rechromatography of such a preparation, an additional peak was observed which moved between ${ }^{125} \mathrm{I}-\mathrm{BH}-\mathrm{SP}$ and substance $\mathrm{P}$. This additional radioactive peak was converted to ${ }^{125} \mathrm{I}-\mathrm{BH}-\mathrm{SP}$ upon incubation with $2 \mathrm{M}$ dithiothreitol at $80^{\circ} \mathrm{C}$ for $2 \mathrm{hr}$, a condition known to convert substance $\mathrm{P}$ sulfoxide to substance $P$ (Floor and Leeman, 1980). Thus, it is essential to prepare ${ }^{125}$ I-BH-SP under anaerobic conditions.

Among reports attempting to demonstrate the binding of radioactive ligands to the substance $P$ receptor, only $\left[{ }^{3} \mathrm{H}\right]$ substance $\mathrm{P}$ binding to the rabbit (Nakata et al., 1978) and rat brain membranes (Hanley et al., 1980b) were characterized extensively by competition with fragments of substance $P$. Interestingly, (pyroGlu ${ }^{6}$ 11)substance $P$ has a binding affinity 1.7-fold that of substance $P$ in rat brain membranes and only 0.005 -fold that of substance $P$ in our parotid cell binding, whereas the deca(2-11), nona(3-11), and octa(4-11) fragments and physalaemin have a remarkably similar potency in these two systems. (pyroGlu ${ }^{6}-11$ )Substance $P$ also has been reported to be more potent than substance $P$ (5- to 12-fold) in depolarizing rat spinal neurons (Otsuka and Konishi, 1977), but it is less potent than substance $P$ (0.17-fold) in stimulating salivation as reported here and 
by others (Hanley et al., 1980d; Leeman et al., 1977). Although other explanations are possible, it is tempting to speculate that the substance $P$ receptor in the nerve tissues may not be identical to that in the parotid gland. Multiple types of receptors for histamine (Hirschowitz, 1979) and epinephrine (Kunos, 1976) have been documented.

Our data suggest that ${ }^{125} \mathrm{I}-\mathrm{BH}$-SP binds to a membrane receptor for substance $P$ (Table II). We are carrying out autoradiographic studies in order to determine whether ${ }^{125} \mathrm{I}-\mathrm{BH}-\mathrm{SP}$ binds to the cell surface membrane or to intracellular membranes. Preliminary results indicate that, after the incubation of cells with ${ }^{125} \mathrm{I}-\mathrm{BH}-\mathrm{SP}$ at $20^{\circ} \mathrm{C}$ for $20 \mathrm{~min}$, the silver granules were present mainly on the surface of acinar cells. The cell surface granules largely disappeared when substance $\mathbf{P}(2.5 \mu \mathrm{M})$ was included in the binding incubation. Thus, ${ }^{125} \mathrm{I}-\mathrm{BH}-\mathrm{SP}$ may bind to a cell surface receptor.

Although phospholipids have a high affinity for $\left[{ }^{125} \mathrm{I}-\right.$ Tyr $\left.{ }^{8}\right]$ substance $\mathrm{P}\left(K_{d}=0.3 \mathrm{~nm}\right.$; Mayer et al., 1979; Lembeck et al., 1979), the ligand specificity is not that expected for receptor binding since physalaemin, $\left[\mathrm{Tyr}^{8}\right.$ ]substance $\mathrm{P}$, and eledoisin, all potent analogs of substance $P$ (Konishi and Otsuka, 1974; Rosell et al., 1977), do not inhibit the binding. We provide a preliminary indication that the substance $P$ receptor on the parotid cells may involve a protein. However, further studies are required to determine the chemical nature of the receptor.

We estimate that the number of substance $\mathrm{P}$ binding sites on rat parotid cells is $49 \pm 17 \mathrm{fmol} / \mathrm{mg}$ of protein which is significantly higher than that reported (1.67 $\mathrm{fmol} / \mathrm{mg}$ of protein or 200 sites/cell) by Putney et al. (1980). The major differences between the two systems is that they used ${ }^{125} \mathrm{I}$-physalaemin prepared by the chloramine $T$ method and their binding incubation was carried out at a higher temperature $\left(37^{\circ} \mathrm{C}\right)$ in the absence of protease inhibitors. It is conceivable that a major portion of the ${ }^{125} I$-physalaemin preparation is in the sulfoxide form. In addition, higher temperatures facilitate degradation of the radioactive ligand during the binding incubation. The higher nonspecific binding (78\% of total) and low total binding using ${ }^{125} \mathrm{I}$-physalaemin may result in an underestimation of the number of specific binding sites.

${ }^{125} \mathrm{I}-\mathrm{BH}-\mathrm{SP}$ binding to the parotid cells should be a useful system for screening for substance $P$ agonists and antagonists and ${ }^{125} \mathrm{I}-\mathrm{BH}-\mathrm{SP}$ may also be used to characterized the substance $P$ receptor in other tissues.

\section{References}

Bolton, A. E., and W. M. Hunter (1973) The labelling of proteins to high specific radioactivities by conjugation to a ${ }^{125} \mathrm{I}-\mathrm{con}$ taining acylating agent. Biochem. J. 133: 529-539.

Bradford, M. M. (1976) A rapid and sensitive method for the quantitation of microgram quantities of protein utilizing the principle of protein dye binding. Anal. Biochem. 72: 248-254.

Brown, C. L., and M. R. Hanley (1981) The effects of substance $\mathrm{P}$ and related peptides on $\alpha$-amylase release from rat parotid gland slices. Br. J. Pharmacol. 73: 517-523.

Bury, R. W., and M. L. Mashford (1977) A pharmacological investigation of synthetic substance $P$ on the isolated guinea pig ileum. Clin. Exp. Pharmacol. Physiol. 4: 453-461.

Cascieri, M. A., M. M. Goldenberg, and T. Liang (1981) Biolog- ical activity of substance P methyl ester. Mol. Pharmacol. 20: 457-459.

Costa, M., A. C. Cuello, J. B. Furress, and R. Franco (1980) Distribution of enteric neurons showing immunoreactivity for substance $P$ in the guinea pig ileum. Neuroscience 5: 323331.

Floor, E., and S. E. Leeman (1980) Substance P sulfoxide: Separation from substance $\mathrm{P}$ by high-pressure liquid chromatography, biological and immunological activities and chemical reduction. Anal. Biochem. 101: 498-503.

Hanley, M. R., C. M. I.ee, I. M. Jones, and R. H. Michell (1980a) Similar effects of substance $P$ and related peptides on salivation and phosphatidylinositol turnover in rat salivary glands. Mol. Pharmacol. 18: 78-83.

Hanley, M. R., B. E. B. Sandberg, C. M. Lee, L. L. Iversen, D. E. Brundish, and R. Wade (1980b) Specific binding of ${ }^{3} \mathrm{H}$. substance $\mathrm{P}$ to rat brain membranes. Nature $286: 810-812$.

Hirschowitz, B. I. (1979) Histamine receptors. Annu. Rev. Pharmacol. Toxicol. 19: 203-244.

Hokfelt, T., O. Johansson, J. -O. Kellerth, A. Ljungdahl, G. Nilsson, A. Nygards, and B. Pernow (1977) Immunohistochemical distribution of substance P. In Substance P, U. S. von Euler and B. Pernow, eds., pp. 117-145, Raven Press, New York.

Jensen, R. T., and J. D. Gardner (1979) Interaction of physalaemin, substance $\mathrm{P}$ and eledoisin with specific membrane receptors on pancreatic acinar cells. Proc. Natl. Acad. Sci. U. S. A. 76: 5679-5683.

Konishi, S., and M. Otsuka (1974) The effects of substance P and other peptides on spinal neurons of the frog. Brain Res. 65: 397-410.

Kunos, G. (1976) Adrenoreceptors. Annu. Rev. Pharmacol. Toxicol. 18: 291-311.

Langone, J. J. (1980) Radioiodination by use of the BoltonHunter and related reagents. Methods Enzymol. 70: 221-243.

Leeman, S. E., and K. Hammerschlag (1967) Stimulation of salivary secretion by a factor extracted from hypothalamic tissue. Endocrinology 85: 803-810.

Leeman, S. E., E. A. Mroz, and R. E. Carraway (1977) Substance $\mathrm{P}$ and neurotensin. In Peptides in Neurobiology, H. Gainer, ed., pp. 99-144, Plenum Press, New York.

Lembeck, F., A. Saria, and N. Mayer (1979) Substance P: Model studies of its binding to phospholipids. Naunyn-Schmiedebergs Arch. Pharmacol. 306: 189-198.

Liang, T., and M. A. Cascieri (1979) Substance P stimulation of amylase release by isolated parotid cells and inhibition of substance $\mathbf{P}$ induction of salivation by vasoactive peptides. Mol. Cell. Endocrinol. 15: 151-162.

Liang, T., and M. A. Cascieri (1980) Specific binding of an immunoreactive and biologically active ${ }^{125}$ I-labelled $\mathrm{N}$ (1)acylated substance $\mathrm{P}$ derivative to parotid cells. Biochem. Biophys. Res. Commun. 96: 1793-1799.

Mayer, N., F. Lembeck, A. Saria, and R.. Gamse (1979) Substance P: Characteristics of binding to synaptic vesicles of rat brain. Naunyn-Schmiedebergs Arch. Pharmacol. 306: 45-51.

Nakata, Y., Y. Kusaka, T. Segawa, H. Yajima, and K. Kitagawa (1978) Substance P: Regional distribution and specific binding to synaptic membranes in rabbit central nervous system. Life Sci. 22: 259-268.

Nicoll, R. A., C. Schenker, and S. E. Leeman (1980) Substance $\mathrm{P}$ as a transmitter candidate. Annu. Rev. Neurosci. 3: 227268.

Nilsson, G., and E. Brodin (1977) Tissue distribution of substance P-like immunoreactivity in dog, cat, rat, and mouse. In Substance P, U. S. von Euler and B. Pernow, eds., pp. 4954, Raven Press, New York.

Ogata, N. (1979) Substance P causes direct depolarization of neurons of guinea pig interpeduncular nucleus in vitro. $\mathrm{Na}$ ture 277: $480-481$ 
Otsuka, M., and S. Konishi (1977) Electrophysiological and neurochemical evidence for substance $P$ as a transmitter of primary sensory neurons. In Substance $P$, U. S. von Euler and B. Pernow, eds., pp. 207-214, Raven Press, New York.

Pernow, B. (1980) Morphological and functional aspects of substance P. In Neuropeptides and Neural Transmission, C. A. Marsan and W. Z. Traczyk, eds., pp. 5-17, Raven Press, New York.

Phillis, J. W., and J. J. Limacher (1974) Substance P excitation of cerebral cortical Betz cells. Brain Res. 69: 158-163.

Putney, J. W., Jr., C. M. Van De Walle, and C. S. Wheeler (1980) Binding of ${ }^{125} \mathrm{I}$-physalaemin to rat parotid acinar cells. J. Physiol. (Lond.) 301: 205-212.
Rosell, S., U. Bjorkroth, D. Chang, I. Yamaguchi, Y. -P. Wan, G. Rackur, G. Fisher, and K. Folkers (1977) Effects of substance $P$ and analogs on isolated guinea pig ileum. In $S u b$ stance $P$, U. S. von Euler and B. Pernow, eds., pp. 83-88, Raven Press, New York.

Sjodin, I., E. Brodin, G. Nilsson, and T. P. Conlon (1980) Interaction of substance $\mathrm{P}$ with dispersed pancreatic acinar cells from the guinea pig: Binding of radiolabelled peptide. Acta Physiol. Scand. 109: 97-105.

Tregear, G. W., H. D. Niall, J. T. Potts, Jr., S. E. Leeman, and M. M. Chang (1971) Synthesis of substance P. Nature New Biol. 232: 87-89. 